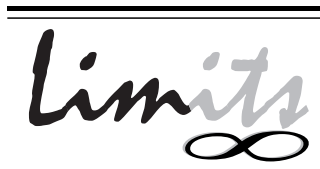

J. Math. and Its Appl.

ISSN : $1829-605 \mathrm{X}$

Vol. 8, No. 2, November 2011, 9-15

\title{
SOLUSI NUMERIK DARI PERSAMAAN NAVIER-STOKES
}

\author{
Chairul Imron, Suhariningsih, B. Widodo and T. Yuwono \\ Post Graduate Student of Universitas Airlangga (Unair) and \\ Lecturer of Institut Teknologi Sepuluh Nopember (ITS), Surabaya, Indonesia, \\ imron-its@matematika.its.ac.id
}

\begin{abstract}
Abstrak
Interaksi antara aliran fluida dengan suatu benda sering ditemui di alam. Aliran laminar maupun turbulen yang melewati suatu permukaan benda, maka partikel-partikel di sekitar permukaan bergerak lambat akibat gaya viskos, sehingga kecepatan partikel tersebut relatif nol. Pada paper ini akan mengkaji solusi numerik untuk menyelesaikan persamaan Navier-Stokes yang diterapkan pada persegi sirkuler yang dialiri fluida.
\end{abstract}

Katakunci: Persamaan Navier-Stokes, Numerik.

\section{Pendahuluan}

Penelitian yang berkesinambungan akan menghasilkan teknologi yang canggih dan akan merubah perilaku manusia terhadap teknologi itu sendiri. Penelitian dapat dilakukan dengan eksperimen maupun simulasi, dengan harapan hasil penelitian tersebut bermanfaat untuk masa yang akan datang. Salah satu bidang penelitian yang banyak diteliti adalah bidang penelitian dinamika fluida, yaitu penelitian mengenai aliran fluida yang melalui silinder utama yang berbentuk silinder sirkular. 
Interaksi antara aliran fluida dengan suatu benda sering ditemui di alam. Beberapa contoh tersebut adalah tiang pancang bangunan lepas pantai, struktur jembatan layang atau produk-produk teknik lainnya seringkali dirancang secara berkelompok. Benda tersebut akan menerima beban dari atas dan juga menerima beban dari sekelilingnya. Benda tersebut biasanya dinamakan dengan body atau bluff bo$d y$ dengan bentuk geometri yang bermacam-macam dan biasanya berkelompok. Bentuk geometri dari benda merupakan faktor utama yang harus diperhitungkan dalam perancangan, karena aliran fluida yang melewatinya akan mempunyai karakteristik yang berbeda, begitu juga jika benda tersebut berdiri sendiri atau berkelompok.

Aliran laminar maupun turbulen yang melewati suatu permukaan benda, maka partikel-partikel di sekitar permukaan bergerak lambat akibat gaya viskos (viscous force), sehingga kecepatan partikel tersebut relatif nol. Sementara fluida yang lain berusaha untuk bergerak lambat di atas partikel yang relatif diam sebagai akibat interaksi antara gerakan fluida yang lebih cepat dan fluida yang lebih lambat. Hal ini merupakan fenomena yang dapat meningkatkan gaya atau tegangan geser. Lapisan yang kecepatannya terpengaruh oleh tegangan geser akibat gaya viskositas disebut lapisan batas (boundary layer).

Penelitian tentang fenomena aliran fluida yang melintasi permukaan luar suatu benda berkembang sangat pesat. Konsep lapisan batas berhasil menguak sejumlah jawaban atas pengaruh tegangan geser yang memegang peranan penting terhadap karakteristik gaya hambat di sekitar benda yang dialiri fluida. Beberapa penelitian yang telah dilakukan yaitu aliran fluida yang melalui sebuah silinder sirkuler tunggal[1], silinder sirkuler yang dimodifikasi menjadi tipe $D$ atau tipe $I[2,3]$. Aliran fluida yang melalui lebih dari satu silinder dengan ukuran yang berbeda dan tersusun tandem[4, 5, 6, 7], semua hasil eksperimen tersebut digambarkan dalam sebuah album oleh Milton[8].

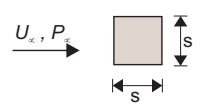

\section{Gambar 1: Domain Kajian}

Aliran fluida yang mengalir melintasi suatu profil silinder tegak akan menghasilkan gaya hambat yang seringkali merugikan. Besar kecilnya gaya hambat dipengaruhi oleh beberapa parameter, salah satunya adalah koefisien hambat (drag 
coefisien, $C_{D}$ ). Salah cara untuk mengurangi gaya hambat pada silinder utama adalah dengan menambah silinder kecil didepan sillinder utama yang dinamakan dengan passive control. Eksperimen yang sudah dilakukan dengan cara tersebut dapat mengurangi koefisien hambat sebesar $48 \%$ dibanding tanpa passive control[4], juga dilakukan dengan bilangan Reynolds yang berbeda yang hasilnya minimum pressure coefisien, $C_{p_{m i n}}$ yang terjadi akan semakin rendah[5].

Penelitian-penelitian di atas kebanyakan dilakukan dengan melakukan eksperimen, paper ini akan mengkaji penyelesaian numerik yang diterapkan pada aliran fluida yang melewati silinder sirkuler pada dimensi dua seperti pada Gambar 1.

\section{Penyelesaian Navier-Stokes}

Diasumsikan aliran yang digunakan adalah laminar, incompressible dan berada pada dimensi dua. Persamaan gerak dan kontinu untuk fluida Newtonian adalah persamaan Navier-Stokes yang ditulis seperti berikut ini,

$$
\begin{aligned}
& \frac{\partial \mathbf{u}}{\partial t}+\mathbf{u} \nabla \mathbf{u}=-\nabla P+\frac{1}{R e} \nabla^{2} \mathbf{u} \\
& \nabla \cdot \mathbf{u}=0 .
\end{aligned}
$$

dengan $\mathbf{u}$ adalah kecepatan, $P$ adalah tekanan, dan $R e$ adalah bilangan Reynolds. Beberapa cara penyelesaian dari persamaan tersebut, salah satunya adalah dengan mengabaikan sementara tekanan, dengan demikian persamaan di atas berubah menjadi

$$
\begin{aligned}
\frac{\partial \mathbf{u}}{\partial t} & =-\mathbf{u} \nabla \mathbf{u}+\frac{1}{R e} \nabla^{2} \mathbf{u} \\
\nabla \cdot \mathbf{u} & =0
\end{aligned}
$$

Persamaan 2 diselesaikan terlebih dahulu, sehingga didapat $\mathbf{u}$, kemudian didapat persamaan berikut

$$
\frac{\partial \mathbf{u}}{\partial t}=\frac{\mathbf{u}^{* *}-\mathbf{u}^{*}}{\Delta t}=-\nabla P
$$

didivergensikan bagian kanan dan kiri, diperoleh

$$
\frac{\nabla \cdot \mathbf{u}^{* *}-\nabla \cdot \mathbf{u}^{*}}{\Delta t}=-\nabla^{2} P
$$

dengan mempertimbangkan Persamaan 3, maka

$$
\nabla \cdot \mathbf{u}^{* *}=0
$$

dan menjadi persamaan Poisson, yaitu

$$
\nabla^{2} P=\frac{1}{\Delta t} \nabla \cdot \mathbf{u}^{*}
$$


hitung $\nabla \cdot \mathbf{u}^{*}$ terlebih dahulu, sehingga $P$ ditemukan. Setelah $P$ ditemukan, kembali ke Persamaan 4 untuk mendapatkan $\mathbf{u}$ sebenarnya.

\section{Kajian Numerik}

Untuk menyelesaikan suatu persamaan dengan menggunakan numerik yang perlu diperhatikan adalah posisi dari setiap peubah dengan peubah yang lain. Pada Gambar 2, tiga tipe penentuan posisi dari peubah yang digunakan, yaitu $u, v$ dan $p$, Gambar 2(a) posisi peubah $u_{i, j}, v_{i, j}$ dan $p_{i, j}$ terletak satu titik dinamakan dengan tipa $A$, sedangkan Gambar 2(b), posisi peubah $u_{i, j}$ dan $v_{i, j}$ dalam satu titik serta peubah $p_{i, j}$ diposisi yang berbeda, dinamakan dengan tiep $B$. Dan yang ketiga, Gambar 2(c), ketiga peubah tidak terletak pada titik yang sama dinamakan dengan tipe $C$.

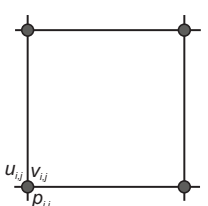

(a)

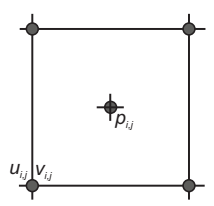

(b)

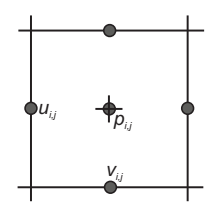

(c)

Gambar 2: Macam grid

Pada paper ini akan digunakan ketiga peubah dengan tiga titik yang berbeda, seperti pada Gambar 3. Dari Persamaan 2 dapat ditulis dalam numerik sebagai
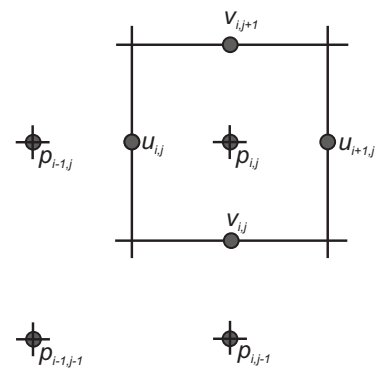

Gambar 3: Posisi grid 
berikut

$$
\begin{aligned}
& \frac{\partial u}{\partial t}=-u^{n} \frac{\partial u^{n}}{\partial x}-v^{n} \frac{\partial u^{n}}{\partial y}+\frac{1}{R_{e}}\left(\frac{\partial^{2} u^{n}}{\partial x^{2}}+\frac{\partial^{2} u^{n}}{\partial y^{2}}\right) \\
& \frac{\partial v}{\partial t}=-u^{n} \frac{\partial v^{n}}{\partial x}-v^{n} \frac{\partial v^{n}}{\partial y}+\frac{1}{R_{e}}\left(\frac{\partial^{2} v^{n}}{\partial x^{2}}+\frac{\partial^{2} v^{n}}{\partial y^{2}}\right)
\end{aligned}
$$

untuk kecepatan arah datar, didapat

$$
\begin{aligned}
\frac{\partial u^{n}}{\partial x} & =\frac{2 u_{i+1, j}^{n}+3 u_{i, j}^{n}-6 u_{i-1, j}^{n}+u_{i-2, j}^{n}}{6 d x}, \\
\frac{\partial u^{n}}{\partial y} & =\frac{2 u_{i, j+1}^{n}+3 u_{i, j}^{n}-6 u_{i, j-1}^{n}+u_{i, j-2}^{n}}{6 d y} \\
\frac{\partial^{2} u^{n}}{\partial x^{2}} & =\frac{u_{i+1, j}^{n}-2 u_{i, j}^{n}+u_{i-1, j}^{n}}{d x^{2}}, \quad \text { dan } \\
\frac{\partial^{2} u^{n}}{\partial y^{2}} & =\frac{u_{i, j+1}^{n}-2 u_{i, j}^{n}+u_{i, j-1}^{n}}{d y^{2}}
\end{aligned}
$$

dan untuk kecepatan arah tegak, didapat

$$
\begin{aligned}
\frac{\partial v^{n}}{\partial x} & =\frac{2 v_{i+1, j}^{n}+3 v_{i, j}^{n}-6 v_{i-1, j}^{n}+v_{i-2, j}^{n}}{6 d x}, \\
\frac{\partial v^{n}}{\partial y} & =\frac{2 v_{i, j+1}^{n}+3 v_{i, j}^{n}-6 v_{i, j-1}^{n}+v_{i, j-2}^{n}}{6 d y} \\
\frac{\partial^{2} v^{n}}{\partial x^{2}} & =\frac{v_{i+1, j}^{n}-2 v_{i, j}^{n}+v_{i-1, j}^{n}}{d x^{2}}, \quad \text { dan } \\
\frac{\partial^{2} v^{n}}{\partial y^{2}} & =\frac{v_{i, j+1}^{n}-2 v_{i, j}^{n}+v_{i, j-1}^{n}}{d y^{2}}
\end{aligned}
$$

sehingga nilai $u^{n+1}$ dan $v^{n+1}$ ditemukan, yaitu

$$
\begin{aligned}
& u^{*}=u^{n}+\Delta t\left(-u^{n} \frac{\partial u^{n}}{\partial x}-v^{n} \frac{\partial u^{n}}{\partial y}+\frac{1}{R_{e}}\left(\frac{\partial^{2} u^{n}}{\partial x^{2}}+\frac{\partial^{2} u^{n}}{\partial y^{2}}\right)\right) \\
& v^{*}=v^{n}+\Delta t\left(-u^{n} \frac{\partial v^{n}}{\partial x}-v^{n} \frac{\partial v^{n}}{\partial y}+\frac{1}{R_{e}}\left(\frac{\partial^{2} v^{n}}{\partial x^{2}}+\frac{\partial^{2} v^{n}}{\partial y^{2}}\right)\right)
\end{aligned}
$$

Persamaan 5 dapat ditulis seperti dibawah ini

$$
\nabla^{2} P^{n+1}=\frac{1}{\Delta t} \nabla \cdot \mathbf{u}^{*}=\rho
$$

hitung terlebih dahulu divergensi dari $\mathbf{u}$, yaitu

$$
\nabla \cdot \mathbf{u}^{*}=\frac{u_{i+1, j}^{*}-u_{i, j}^{*}}{\Delta x}+\frac{v_{i, j+1}^{*}-v_{i, j}^{*}}{\Delta y}
$$


sehingga nilai $\rho$ didapat. Kemudian mencari nilai $P$, dengan cara menyelesaikan persamaan Poison, yaitu

$$
\frac{P_{i+1, j}^{n}-2 P_{i, j}^{n+1}+P_{i-1, j}^{n}}{\Delta x^{2}}+\frac{P_{i, j+1}^{n}-2 P_{i, j}^{n+1}+P_{i, j-1}^{n}}{\Delta y^{2}}=\rho_{i, j}
$$

atau

$$
P_{i, j}^{n+1}=\left(\frac{P_{i+1, j}^{n}+P_{i-1, j}^{n}}{\Delta x^{2}}+\frac{P_{i, j+1}^{n}+P_{i, j-1}^{n}}{\Delta y^{2}}-\rho_{i, j}\right) \frac{\Delta x^{2} \Delta y^{2}}{2\left(\Delta x^{2}+\Delta y^{2}\right)}
$$

dan yang terakhir adalah menghitung

$$
\frac{\partial \mathbf{u}}{\partial t}=-\nabla P
$$

Hasil dari eksekusi program dengan $R e=100$ dengan ukuran grid $600 \times 300$, ukuran persegi $30 \times 30$ terletak pada posisi $(120,150)$ dan diputar dengan 250 satuan.

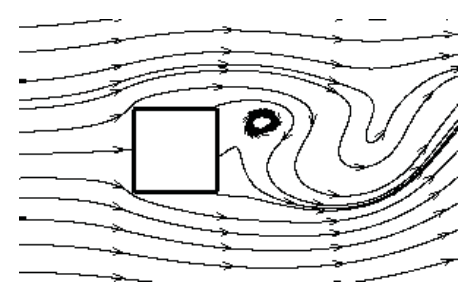

Gambar 4: Streamline tipe $A$ dengan $R e=100$

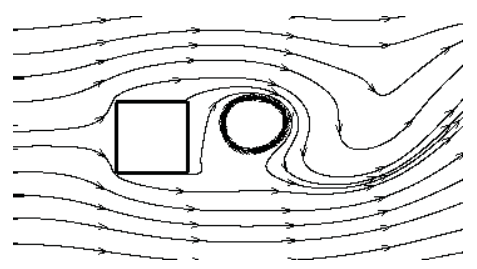

Gambar 5: Streamline tipe $B$ dengan $R e=100$

\section{Pustaka}

[1] Ladjedel,A.O., Yahiaoui,B.T., Adjlout,C.L., and Imine,D.O., Experimental and Numerical Studies of Drag Reduction on Circular Cylinder, World Academy of Sciences, Engineering and Technology, 77 357-361, 2011. 


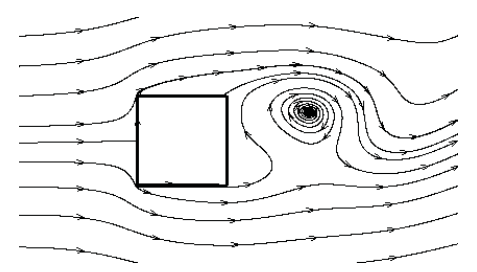

Gambar 6: Streamline tipe $C$ dengan $R e=100$

[2] Igarashi T., and Shiba Y., Drag Reduction for D-Shape and I-Shape Cylinders (Aerodynamics Mechanism of ReductionDrag), JSME International Journal, Series B, 49, No. 4 1036-1042, 2006.

[3] Triyogi Y., and Wawan Aries Widodo, Flow Characteristics Around a D-Type Cylinder Near a Plane Wall, Regional Conferences on Mechanical and Aerospace Technology, Bali, February $9^{\text {st }}-10^{\text {st }}, 2010$.

[4] Bouak, F. and Lemay, J., Passive Control of The Aerodynamic Forces Acting on a Circular Cylinder, Experimental Thermal and Fluid Science, 16 112-121, 1998.

[5] Tsutsui, T., and Igarashi, T., Drag Reduction of a Circular Sylinder in an Air-Stream, Journal of Wind Engineering and Industrial Aerodynamics, 90, 527-541, 1998.

[6] Triyogi Y. and Nuh, M., Using of a Bluff Body Cut from a Circular Cylinder as passive Control to reduce Aerodynamics Forces on a Circular Cylinder, The International Conference on Fluid and Thermal energy Conversion 2003, Bali, Indonesia, December $7^{\text {st }}-11^{\text {st }}, 2003$.

[7] Lee, Sang-Joon., Lee, Sang-Ik., and Park, Cheol-Woo, Reducing the Drag on a Circular Cylinder by Upstream Installation of a Small Control Rod, Fluid Dynamic Research, 34 233-250, 2004

[8] Milton van Dyke, An Album of Fluid Motion, The Parabolics Press, Stanford, Caifornia, 1988. 